\title{
Identification of reduced plant uptake and reduction effects of azoxystrobin, procymidone and tricyclazole by biochars and quicklime
}

\author{
Hyo-Sub Lee ${ }^{1}$ iD $\cdot$ In-Seong Hwang ${ }^{2} \cdot$ Sang-Won Park $^{1} \cdot$ Geun-Hyoung Choi $^{1}$ \\ - Song-Hee Ryu ${ }^{1}$
}

\section{토양 중 바이오차, 생석회를 이용한 azoxystrobin, procymidone 및 tricyclazole 저감화 효과 연구}

이효섭 ${ }^{1} \cdot$ 황인성 $^{2} \cdot$ 박상원 $^{1} \cdot$ 최근형 ${ }^{1} \cdot$ 류송희 $^{1}$

Received: 6 August 2020 / Accepted: 17 September 2020 / Published Online: 30 September 2020

(C) The Korean Society for Applied Biological Chemistry 2020

\begin{abstract}
As pesticide safety was extended to agricultural environments and Positive List System was carried out, Pesticide safety management in soils has become even more important. To improve pesticide safety in soils needs the degradation technology of the residues in soils and reduce plant uptake of pesticides. In this study, biochars and quicklime as the degradation methods of pesticides (azoxystrboin, procymidone and tricyclazole) were used to identify the reduction effects. The experimental methods were putting biochars and quicklimes $(0,0.5,1.0,2.0 \%$ per $15 \mathrm{~cm}$ soil weight) in soils and analyzing the pesticide residues at 0,10 , 20, 35, 50 day. To identify the reduction effects of uptake from soil to korean cabbages (roots, leave, stems) by biochar treatment, the residues in samples were analyzed. As a results, azoxystrobin (36-96\%), procymidone (40-117\%) and tricyclazole (26-83\%) were reduced in soils when treated with $2.0 \%$ quicklime $(p$
\end{abstract}

Hyo-Sub Lee $(\triangle)$

E-mail:1hs8255@korea.kr

${ }^{1}$ Chemical Safety Division, Agro-Food and Crop Protection Departement, NAS, Wanju 55365, Repuplic of Korea

${ }^{2}$ Residue Research Department, Hanearl Science, Seongnam 13027, Republic of Korea

This is an Open Access article distributed under the terms of the Creative Commons Attribution Non-Commercial License (http://creativecommons. org/licenses/by-nc/3.0/) which permits unrestricted non-commercial use, distribution, and reproduction in any medium, provided the original work is properly cited.
$<0.05)$. There were no reduction effect in soils when treated with $1.0 \%$ or less biochar. However, the amounts of residues translocated to roots $(0.11-1.62 \mathrm{mg} / \mathrm{kg})$, leave $(0.05-0.29 \mathrm{mg} / \mathrm{kg})$, stems $(0.06-$ $0.1 \mathrm{mg} / \mathrm{kg}$ ) were reduced treated with $2.0 \%$ biochar treatments. The biochar and quicklime can be applicable to agricultural field to improve pesticide safety in soils.

Keywords Biochar Pesticides $\cdot$ Quicklime $\cdot$ Reduction effects - Uptake

\section{서 론}

농약의 사용은 농업의 생산성 증대와 식량문제를 해결하였고, 노동력 절감 및 농산물의 질을 향상시키는데 크게 공헌하였다. 농약은 독성을 가지는 물질로서 그 독성성분을 이용하여 병 해충을 예방을 하기 때문에 적절한 관리방안이 필요하다. 농산 물 안전성을 위해서 농약의 1일 섭취허용량(acceptable daily intake)과 국민 평균체중, 식품별 1 일 섭취량, 농산물 중 실제 농약 잔류량을 고려하여 농약의 잔류허용기준(maximum residue limit, MRL)을 정하고 있다. 농업현장에서는 농산물 $\mathrm{MRL}$ 을 초 과하지 않기 위해서 안전사용기준을 준수하여 농약을 살포하고 있다. 그러나, 최근에는 농약 안전성 범위가 환경까지 확대되면 서 토양 중 농약 안전관리 또한 중요하게 인식되고 있다. 토양 중 잔류농약은 수직 - 수평이동을 하여, 지하수 오염을 일으키 고, 또한 토양생물 및 유용미생물에 영향을 주어서 작물생육 등 
부정적 영향을 주는 것으로 알려져 있다[1-3].

2019년 Positive List System (PLS)가 시행되면서, 토양 잔류 농약의 비의도적 오염은 가장 큰 관심이 되었다. PLS는 $\mathrm{MRL}$ 이 설정되지 않은 농약을 $0.01 \mathrm{mg} / \mathrm{kg}$ 으로 일률적으로 관리하는 제도이다. 이 제도가 시행되면 토양 중 전작물에 사용한 농약 (후작물 미등록 농약)이 후작물로 전이되어 $0.01 \mathrm{mg} / \mathrm{kg}$ 초과할 경우 부적합 농산물 원인이 될 수 있다. 기존 연구에서도 토양 중 농약은 후작물 흡수·이행되어 잔류량에 영향을 미칠 수 있 다는 연구결과 보고되었다[4-6]. 우리나라 소면적 다작물의 영 농형태를 나타내는 농가가 많기 때문에 PLS 시행으로 토양 중 잔류농약 안전관리가 필요한 실정이다.

비의도적 오염을 예방하기 위한 방안으로 (1) 농약 잔류량을 감소시키는 저감화 방법 (2) 특정물질에 농약을 흡착시켜 이용 률을 낮추어 작물의 흡수 - 이행량을 저감하는 방법이다. 토양 중 농약 저감화 방법으로는 미생물 활성화 및 가수분해 촉진 등이 대표적이다[7,8]. 경작지에서 쉽게 활용할 수 있는 방법으 로는 토양 개량제 첨가이다. 대표적인 물질로 생석회(Quicklime) 및 바이오차(biochar)이다. 농경지에 생석회를 첨가하면 토양 중 물과 반응하여 $\mathrm{Ca}(\mathrm{OH})_{2}$ 를 생성하며 토양 $\mathrm{pH}$ 를 증가시켜 농약 의 가수분해를 촉진시킨다. 바이오차는 산소가 없는 조건에서 농산물 부산물, 축산 폐기물 등의 물질을 높은 열로 불완전 연 소하여 제조된다. 바이오차의 특징으로 수분 보유성이 좋고, 영 양분도 흡착하여 적당한 양을 토양에 첨가하면서 작물 생육에 도움을 주는 것으로 알려져 있어, 농업에서 많이 활용되고 있 고 생산량 증가 등 이로운 효과가 있다는 보고들도 있다[9-11]. 또한 바이오차의 강한 흡착 특성을 이용하여 유기화학물질을 흡 착하여 작물 흡수 - 이행 저감 및 지하수 오염 방지 등 안전성 연구도 많이 진행되었다[12-14].

이번 연구에서는 생석회 및 biochar를 이용하여 토양 중 잔
류농약 안전관리방안 마련을 목적으로 수행하였다. 포장 토양에 서 생석회를 이용하여 농약 잔류량 저감화와 바이오차를 이용 해 작물(얼갈이 배추) 중 농약 흡수 - 이행 저감효과를 구명하 였다.

\section{재료 및 방법}

\section{농약표준용액 및 시약}

시험 농약은 Park 등(2008)의 농경지 모니터링 연구와 매년 농 산물품질관리원에서 실시하는 농산물 모니터링 결과 중 다빈도 검출농약 azoxystrobin (순도 $99.0 \%$ ), procymidone (99.9\%), tricyclazole (99.5\%) 3종을 선정하였다. 분석에 사용한 표준품은 Dr. Ehrenstorfer GmbH (Ausburg, Bayern, Germany)에서 구 매하여 사용하였고, 각각의 농약은 acetonitrile $(\mathrm{ACN})$ 으로 $1,000 \mathrm{mg} / \mathrm{L}$ 의 stock solution을 제조한 다음 이를 희석하여 10 $\mathrm{mg} / \mathrm{L}$ 의 혼합 working solution을 제조하였다.

분석에 사용한 용매 acetonitrile, glacial acetic acid (100\%) 는 Merck사(Darmstadt, Germany)의 HPLC Grade를 사용하였 고, formic acid ( $>98 \%$ purity)와 ammonium acetate (99\% purity) 는 Sigma Aldrich (St. Louis, MO, USA)에서 구입하여 사용 하였다. 3차 증류수는 Millipore사의 Milli-Q system (Bedford, Bedfordshire, UK)을 사용하여 제조하였다. QuEChERS 전처리 를 위한 시약 및 제품은 Agilent technology (Santa Clara, CA, USA)에서 구입하였다.

\section{토양 중 잔류농약 분석방법}

토양시료 $10 \mathrm{~g}$ 과 $1 \%$ acetic acid in $\mathrm{ACN} 15 \mathrm{~mL}$ 를 혼합하여 QuEChERS 추출기 (1600 MiniG, SPEX sample Prep, Metuchen,

Table 1 Analytical condition of LC-MS/MS and MRM conditions

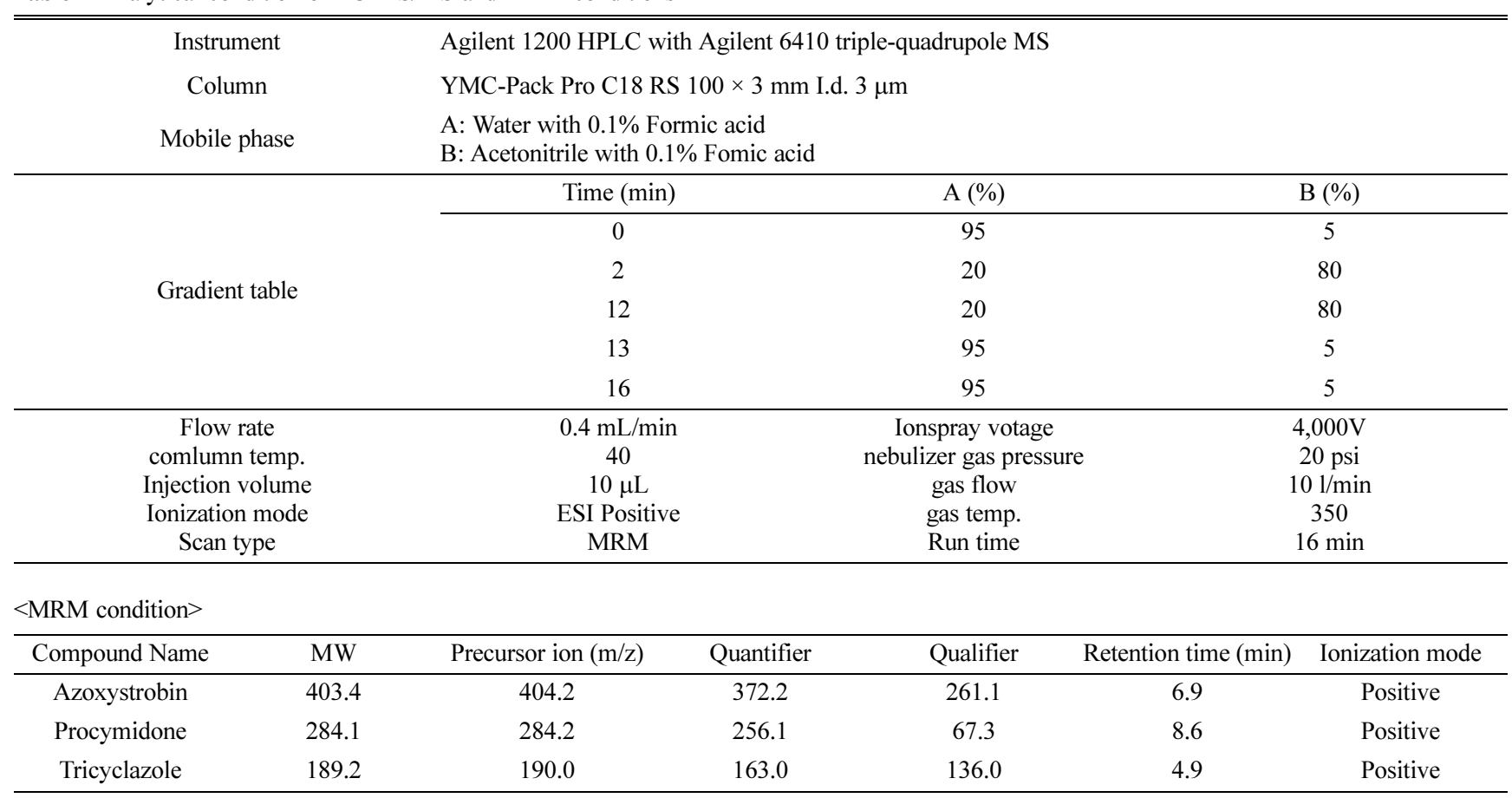


Table 2 Physicochemical properties of the tested soil

\begin{tabular}{|c|c|c|c|c|c|c|c|c|c|c|}
\hline \multirow{2}{*}{ Texture } & \multicolumn{3}{|c|}{ Particle distribution (\%) } & \multirow{2}{*}{$\mathrm{pH}$} & \multirow{2}{*}{$\begin{array}{c}\mathrm{EC} \\
(\mathrm{dS} / \mathrm{m})\end{array}$} & \multirow{2}{*}{$\mathrm{OM}(\mathrm{g} / \mathrm{kg})^{1)}$} & \multirow{2}{*}{$\mathrm{P}_{2} \mathrm{O}_{5}$} & \multicolumn{3}{|c|}{ Exchangeable cations $\left(\mathrm{cmol}_{\mathrm{c}} / \mathrm{kg}\right)$} \\
\hline & Sand & Silt & Clay & & & & & $\mathrm{Ca}$ & $\mathrm{K}$ & $\mathrm{Mg}$ \\
\hline Sandy loam & 73.0 & 17.6 & 9.4 & 5.8 & 1.05 & 10 & 266 & 1.0 & 0.71 & 25.6 \\
\hline
\end{tabular}

OM: Organic Matter

$\mathrm{NJ}, \mathrm{USA}$ )를 이용하여 $1,300 \mathrm{rpm}$ 에서 2분간 추출하였다. $\mathrm{EN}$ Extraction kit $\left(4 \mathrm{~g} \mathrm{MgSO}_{4}, 1 \mathrm{~g} \mathrm{NaCl}, 1 \mathrm{~g} \mathrm{NaCitrate,} 0.5 \mathrm{~g}\right.$ disodiumcitratesesquihydrate) 을 첨가하였고 QuEChERS 추출기 를 이용해 $1,300 \mathrm{rpm}$ 에서 30 초간 흔들어준 후 $3,500 \mathrm{rpm}, 5$ 분 $\left(4^{\circ} \mathrm{C}\right)$ 조건으로 원심분리(Combi-514R, Hanil, Gimpo, Korea)하 였다. 상등액 $1 \mathrm{~mL}$ 를 취하여 $2 \mathrm{~mL} \mathrm{EN-Fatty} \mathrm{acid}(150 \mathrm{mg}$ $\mathrm{MgSO}_{4}, 25 \mathrm{mg}$ primary secondary amine (PSA), $25 \mathrm{mg} \mathrm{C} \mathrm{C}_{18}$ ) 에 첨가한 후 1 분간 흔들어준 후 $3,500 \mathrm{rpm}, 5$ 분 조건에서 원 심분리 하였다. 상등액을 $0.2 \mu \mathrm{m}$ syringe filter을 통과시킨 후 샘플 $500 \mu \mathrm{L}$ 와 $\mathrm{ACN} 500 \mu \mathrm{L}$ 를 vial에 넣은 후 $\mathrm{LC}-\mathrm{MS} / \mathrm{MS}$ 로 기기분석 하였다(Table 1).

\section{얼갈이 배추 중 잔류농약 분석방법}

얼갈이 배추 분석은 잎, 줄기, 뿌리 세 부분을 나누어서 분석을 진행하였다. 잎과 줄기는 $10 \mathrm{~g}$, 뿌리는 $5 \mathrm{~g}$ 을 이용하여 분석에 이용하였다. 시료를 $50 \mathrm{~mL}$ 플라스틱 튜브에 넣은 후 $1 \%$ acetic acid in ACN $15 \mathrm{~mL}$ 를 혼합하여 QuEChERS 추출기(1600 MiniG, SPEX sample Prep)를 이용하여 1,300 rpm에서 2분간 추출하였다. $\mathrm{EN}$ Extraction kit를 첨가하였고 $\mathrm{QuEChERS} \mathrm{추출}$ 기를 이용해 $1,300 \mathrm{rpm}$ 에서 30 초간 흔들어준 후 $3,500 \mathrm{rpm}, 5$ 분 $\left(4^{\circ} \mathrm{C}\right)$ 조건으로 원심분리 하였다. 상등액 $8 \mathrm{~mL}$ 를 취하여 15 $\mathrm{mL}$ EN-Fatty acid $\left(900 \mathrm{mg} \mathrm{MgSO}_{4}, 150 \mathrm{mg}\right.$ PSA, $150 \mathrm{mg}$ $\mathrm{C}_{18}$ )에 첨가한 후 1 분간 흔들어준 후 $3,500 \mathrm{rpm}, 5$ 분 조건에서 원심분리 하였다. 상등액을 $0.2 \mu \mathrm{m}$ syringe filter을 통과시킨 후 샘플 $500 \mu \mathrm{L}$ 와 $\mathrm{ACN} 500 \mu \mathrm{L}$ 를 vial에 넣은 후 $\mathrm{LC}-\mathrm{MS} / \mathrm{MS}$ 로 기기분석 하였다(Table 1).

바이오차 및 생석희 처리한 토양 중 농약의 경시적 잔류량 구명 시험은 전북 완주군의 국립농업과학원의 시설하우스 포장에서 진행을 하였으며 시험기간은 2017년 5-7월 동안 진행하였으며 토양 특성은 Table 2 와 같다. 시험기간 동안 시설하우스 안의 환경 조건은 기온 $28.8{ }^{\circ} \mathrm{C}$, 상대습도 $66.1 \%$ 이었다. 시험농약은 azoxystrobin (21.7\%, 액상수화제), procymidone $(50.0 \%$, 수화 제), tricyclazole $(75.0 \%$, 수화제)를 이용하였으며, 사용된 토양 개량제로 바이오차(훈탄)는 왕겨를 $450{ }^{\circ} \mathrm{C}$ 조건에서 제조한 숯 과, 생석회는 과립으로 제조하여 판매되는 제품을 구매하여 사 용하였다. 토양 중 농약 살포는 작토층 $(15 \mathrm{~cm})$ 을 기준으로 초기 농도 $5 \mathrm{mg} / \mathrm{kg}$ 수준이 되도록 농약을 물에 희석하여 골고루 살 포한 후 토양 균질화 작업을 진행하였다. 토양 균질화 후 토양 개량제 처리구를 각각 $1.6 \mathrm{~m} \times 2.5 \mathrm{~m}$ 로 나누어준 후 작토층 토양 무게를 기준으로 바이차를 $0,0.5,1.0,2.0 \%$ 와 생석회 $0,0.5$, $1.0,2.0 \%$ 로 처리를 하였다. 토양 시료 채취는 농약 살포후 0 (2시간), $10,20,35,50$ 일에 처리구의 5 지점 이상에서 $2 \mathrm{~kg}$ 이 상 채취 후 토양의 수분함량 $6 \%(\mathrm{w} / \mathrm{w})$ 이하 될 때까지 음건 하였다. 음건된 시료는 분석하기 전까지 $-20{ }^{\circ} \mathrm{C}$ 이하에서 보관
하였고, 상기의 방법을 이용하여 분석을 실시하였다.

\section{바이오차 처리에 따른 얼갈이 배추 토양 중 농약 흡수 - 이행 저감효과 구명}

토양 내 바이오차는 유기물질을 흡착시켜 생체이용률을 감소시 키는 효과가 있다. 이러한 왕겨숯 처리가 토양 내 농약이 작물 체로 흡수 - 이행 저감효과를 평가하기 위해서 얼갈이 배추를 이용하여 실험을 진행하였다. 또한 얼갈이 배추는 부위별로의 농약 잔류량 차이를 구명하기 위해서 잎, 줄기 및 뿌리 세 부 분으로 나누어서 분석하였다. 시험농약 3종은 초기농도가 $5 \mathrm{mg} /$ $\mathrm{kg}$ 수준이 되도록 농약을 살포한 후 10 일 동안 토양 안정화 후 얼갈이 배추를 파종하였다. 40 일 동안 재배 후 토양을 마지막 으로 채취하는 시기(농약살포 후 50일)에 함께 채취하여 실험 실로 운반하였다. 얼갈이 배추는 상품성이 있으며 실험에 사용 된 시료의 중량은 $196.2-213.5 \mathrm{~g}$ 이었다. 얼갈이 배추에 뭍은 흙 을 잘 털어준 후 잎, 줄기, 뿌리 세 부분을 나누어 잘라준 후 드라이 아이스와 함께 분쇄하여 분석할 때까지 $-20{ }^{\circ} \mathrm{C}$ 이하에 서 보관 후 상기의 방법을 이용하여 잔류농약을 분석하였다.

\section{회수율 검정 및 표준검량선 작성}

제조한 working solution을 이용하여 $0.005 \quad 0.01,0.05,0.1$, $0.25,0.5 \mathrm{mg} / \mathrm{L}$ 수준으로 무처리 시료를 이용해 희석하여 matrix matched 표준용매를 만들었고, 기기분석조건에서 나타난 chromatography상의 peak 면적을 기준으로 검량선을 작성하였 다. 위의 농도의 peak 면적 값을 이용해 검량선의 직선성을 평 가하였다. LC-MS/MS를 이용한 분석방법의 정량한계는 $0.005-$ $0.01 \mathrm{mg} / \mathrm{kg}$ 로 설정하였다.

농약의 회수율 시험은 무처리 시료에 시험농약 표준용액 10 $\mathrm{mg} / \mathrm{kg}$ 을 이용하여 토양무게 기준 $0.1,1.0 \mathrm{mg} / \mathrm{kg}$ 수준으로 첨가 하였다 $(\mathrm{n}=3)$. 얼갈이 배추는 $0.1,0.5 \mathrm{mg} / \mathrm{kg}$ 수준으로 첨가하였 다 $(\mathrm{n}=5)$. 표준용액 첨가 후 무처리 시료와 혼합 후 30 분간 방 치한 후 상기의 방법으로 회수율을 산출하였다.

\section{통계분석}

모든 실험은 3 반복으로 수행되었으며 실험결과는 R 통계 프로 그램(R version 3. 6. 0.)를 이용하여 처리구간의 유의적인 차이 를 평가하기 위해서 Tukey's HSD검정을 실시하여 분산분석 하 였고, $p<0.05$ 일 때 유의한 차이가 있는 것으로 판단하였다.

\section{결과 및 고찰}

\section{토양 및 얼갈이 배추의 회수율 결과}

토양 및 얼갈이 배추의 회수율 결과는 Table 3, 4와 같다. 토양 에서 3종 농약의 회수율은 77.6-116.9\%, RSD는 1.3-9.4\%이었 
Table 3 Recovery results in the leaf, stem and root of Korean cabbage

\begin{tabular}{|c|c|c|c|c|c|c|}
\hline & & \multicolumn{4}{|c|}{ Korean cabbage } & \multirow{3}{*}{$\begin{array}{c}\text { LOQ } \\
(\mu \mathrm{g} / \mathrm{g})\end{array}$} \\
\hline \multirow{2}{*}{\multicolumn{2}{|c|}{ Compounds }} & \multicolumn{2}{|c|}{$0.1 \mathrm{mg} / \mathrm{kg}$} & \multicolumn{2}{|c|}{$0.5 \mathrm{mg} / \mathrm{kg}$} & \\
\hline & & Recovery (\%) & RSD & Recovery (\%) & RSD & \\
\hline \multirow{3}{*}{ Azoxystrobin } & Leaf & $80.0 \pm 3.5$ & 4.4 & $75.3 \pm 2.6$ & 3.5 & \multirow{3}{*}{0.005} \\
\hline & Stem & $97.2 \pm 5.1$ & 5.2 & $91.2 \pm 4.8$ & 5.3 & \\
\hline & Root & $87.3 \pm 2.1$ & 2.4 & $89.9 \pm 1.3$ & 1.4 & \\
\hline \multirow{3}{*}{ Procymidone } & Leaf & $85.0 \pm 6.9$ & 8.2 & $82.1 \pm 2.6$ & 3.2 & \multirow{3}{*}{0.010} \\
\hline & Stem & $99.2 \pm 3.9$ & 3.9 & $92.6 \pm 4.6$ & 5.0 & \\
\hline & Root & $100.2 \pm 6.2$ & 6.2 & $95.1 \pm 5.1$ & 5.4 & \\
\hline \multirow{3}{*}{ Tricyclazole } & Leaf & $89.6 \pm 1.3$ & 1.4 & $89.7 \pm 1.0$ & 1.1 & \multirow{3}{*}{0.005} \\
\hline & Stem & $94.8 \pm 1.2$ & 1.3 & $95.1 \pm 2.9$ & 3.1 & \\
\hline & Root & $92.0 \pm 3.7$ & 4.0 & $99.6 \pm 3.2$ & 3.2 & \\
\hline
\end{tabular}

Table 4 Recovery results in soils

\begin{tabular}{|c|c|c|c|c|c|}
\hline \multirow{3}{*}{ Compounds } & \multicolumn{4}{|c|}{ Soil } & \multirow{3}{*}{$\begin{array}{c}\text { LOQ } \\
(\mu \mathrm{g} / \mathrm{g})\end{array}$} \\
\hline & \multicolumn{2}{|c|}{$0.1 \mathrm{mg} / \mathrm{kg}$} & \multicolumn{2}{|c|}{$1.0 \mathrm{mg} / \mathrm{kg}$} & \\
\hline & Recovery (\%) & RSD & Recovery (\%) & RSD & \\
\hline Azoxystrobin & $116.9 \pm 11.0$ & 9.4 & $103.9 \pm 2.5$ & 2.4 & 0.005 \\
\hline Procymidone & $85.9 \pm 7.1$ & 8.3 & $90.1 \pm 1.2$ & 1.3 & 0.010 \\
\hline Tricyclazole & $77.6 \pm 1.5$ & 1.9 & $84.0 \pm 1.3$ & 1.5 & 0.005 \\
\hline
\end{tabular}

다. 얼갈이 배추의 회수율은 잎(75.3-89.6\%), 줄기(91.2-99.2\%), 뿌리(87.3-100.2\%) 모두 70-120\% 범위 내이었고, RSD는 $20 \%$ 이하로 적정 회수율 결과를 나타냈다(Table 2, 3).

\section{생석희 처리에 따른 토양 중 농약의 경시적 잔류양상 구명}

농약 처리 후 시험농약 3종(azoxystrobin, procymidone, tricyclazole)의 초기농도는 $6.02,7.82,6.12 \mathrm{mg} / \mathrm{kg}$ 이었다. 토양 중 azoxystrobin과 procymidone은 생석회 처리량이 증가할수록 농약 저감률이 높아지는 것으로 나타났다(Fig. $1, p<0.05$ ).

Azoxystrobin은 생석회 $1 \%$ 이상 처리할 때, 처리 10 일 후 초기농도 대비 $50 \%$ 이상 저감되는 것을 확인할 수 있다. 생석 회를 $2.0 \%$ 처리할 때는 50 일 후 초기농도 대비 약 $90 \%$ 저감 되었으며 무처리 토양 $(53 \%)$ 과 비교할 때 저감효과가 있었다 $(p<0.05)$. Lee 등[3]의 연구에서는 실험실 조건에서 토양 중 생 석회 $2 \%$ 를 처리하고 7 일 후에 azoxystrobin과 procymidone 잔 류량이 $95 \%$ 이상 감소하였고 토양 $\mathrm{pH}$ 가 12.9 까지 증가한 것 이 중요한 요인이라고 하였다. 본 연구는 포장에서 실험을 실 시하여 실험실 조건에서 실시한 Lee 등[3]의 연구처럼 급격한 $\mathrm{pH}$ 증가는 없을 것이지만 azoxystrobin, procymidone 분해촉진 에 $\mathrm{pH}$ 증가가 기여한 것으로 판단된다. 다른 이유로는, 생석회 를 처리할 경우 토양 중 수분과 수화반응하여 $\mathrm{Ca}(\mathrm{OH})_{2}$ 를 생성 한다. 토양이 알칼리화 되어 가수분해에 민감한 농약의 분해가 빨라지고, 반응과정 중 열이 발생하여 휘산 등의 분해촉진효과 를 일으키기 때문이다[15,16]. Azoxystrobin과 procymidone은 $\mathrm{C}=\mathrm{O}$ 결합이 수화반응의 생성물질인 $\mathrm{Ca}(\mathrm{OH})_{2}$ 의 수산화기 $(-\mathrm{OH})$ 가 산화제로서 반응하여 분해가 촉진된 것으로 판단된다. Jung 등[17]의 연구에 의하면 $\mathrm{C}=\mathrm{O}$ 이중결합을 가지고 있는 분자는 수산화기 및 산소 라디칼 원자에 의한 반응으로 분해가 일어난
다고 보고하였다.

Procymidone은 생석회 $1.0 \%$ 이상 처리하였을 때 10 일 후 $90 \%$ 이상 저감효과가 있었고 생석회 $0.5 \%$ 이상 처리하여도 무 처리구 대비 저감효과가 있는 것으로 확인되었다 $(p<0.05)$.

Tricyclazole은 생석회 $2.0 \%$ 이상 처리하였을 때 다른 처리구 대비 저감효과가 $23-29 \% \mathrm{P}$ 이상 높게 나타났다 $(p<0.05)$. Tricyclazole 은 가수분해에 안정한 특성이 있어서(Pesticide Properties DataBase), 다른 농약에 비해 뚜렷한 저감효과가 나타나지 않았 다 $(p>0.05)$. 그러나 생석회 $2.0 \%$ 에서 저감효과가 나타났는데 Yan 등[18]의 연구에 의하면 토양 중 생석회 처리량이 증가할 수록 토양 온도가 증가하고 높은 열 에너지는 토양 중 오염물 질의 휘발을 촉진한다고 보고하였다. 본 연구에서도 토양 중 생 석회 $2 \%$ 처리할 때 휘발로 인해 tricyclazole의 분해효과가 나 타난 것으로 판단된다.

생석회는 토양 $\mathrm{pH}$ 를 높이기 때문에 과도한 사용은 작물 생 육에 영항을 줄 수 있으므로 $\mathrm{pH}$ 를 고려하여 농가에 맞는 정밀 진단이 필요할 것으로 판단된다.

\section{바이오차 처리에 따른 토양 중 농약의 경시적 잔류양상 구명} 토양 중 시험농약 3종(azoxystrobin, procymidone, tricyclazole) 의 초기농도는 $6.0,6.15,6.61 \mathrm{mg} / \mathrm{kg}$ 이었다. 시험결과 바이오차 처리에 따른 농약의 감소양상은 다음과 같다(Fig. 2) 바이오차 를 처리한 토양에서는 농약 처리 10 일 후 농약의 감소속도가 낮아지는 양상을 나타냈다. 바이오차 $1.0 \%$ 이상 처리할 경우 초기(10일 이전)에는 시험농약 azoxystrobin, procymidone 및 tricyclazole의 저감률은 30.9-82.5, 22.4-67.3, 5.8-62.3\%로 무처 리 토양보다 저감률이 높았다 $(p<0.05)$. 바이오차는 토양 중 미 생물을 활성화 시켜 분해를 촉진시키기 때문에 농약 첨가 후 

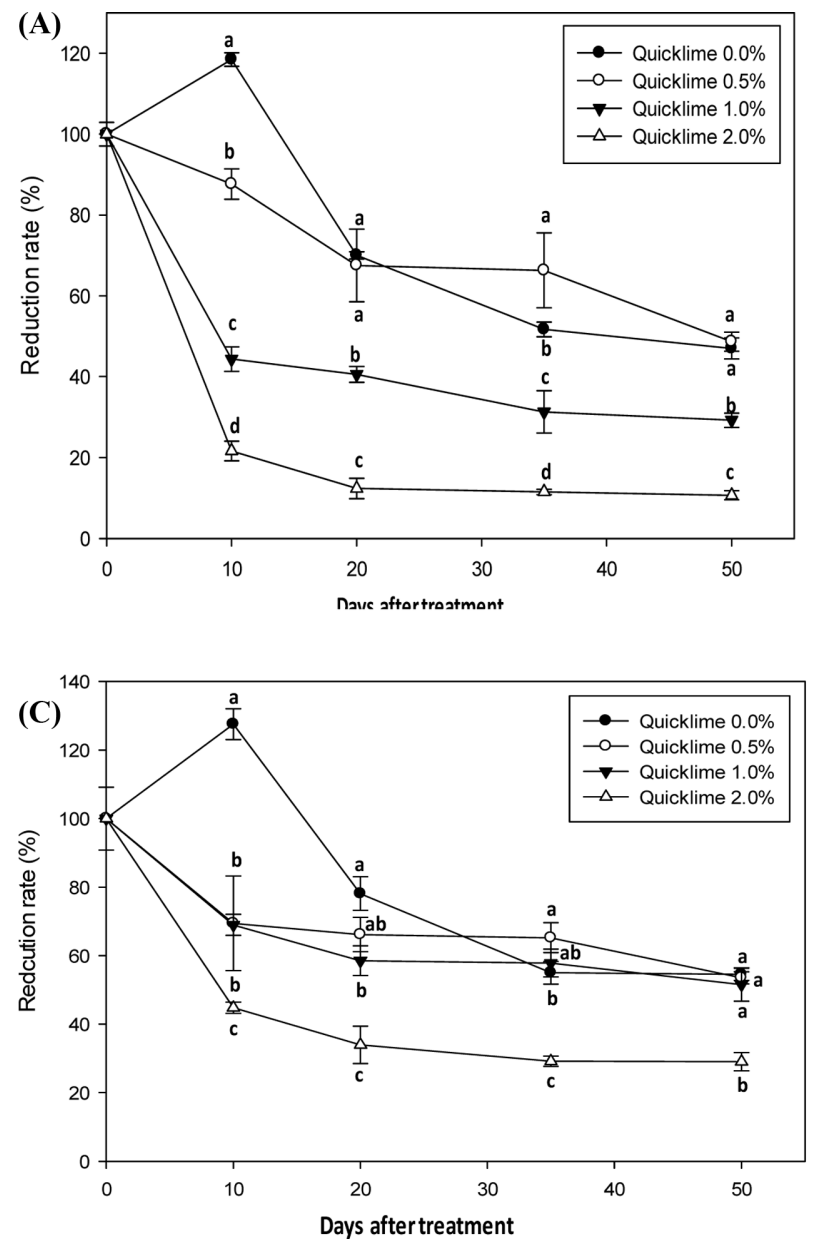

분해속도가 무처리구에 비하여 높은 것으로 판단된다[19-21]. Qiu [20]의 연구에서는 바이오차를 0.1-1.0\%로 투입량을 증가시 킬 때, 미생물의 영양소인 인(Phosphorus) 함량이 증가하면서 생 물학적 분해가 활성화 되어 atrazine 감소률이 높아지는 것으로 보고하였다.

농약 처리 10 일 후부터는 바이오차를 처리한 토양에서 농약 분해율이 일정하게 유지되었는데, 바이오차는 높은 표면적을 가 지는 탄소 구조와 표면에 미세한 공극으로 유기오염물질 흡착 능력이 우수한 것으로 알려졌다[22,23]. 바이오차에 흡착된 유 기오염물질은 안정된 상태로 잔류하여 생물학적 및 비생물학적 인 분해가 일어나기가 일반토양 보다 어렵다[24]. Yu [24]은 상 이한 온도에서 제조한 바이오차와 함량을 조건으로 chlorpyrifos 및 carbofuran의 작물 흡수·이행 연구를 수행했다. 연구결과 높은 온도에서 제조하거나 바이오차 함량이 높을수록 토양 중 농약의 반감기가 증가하였다. 바이오차를 처리할 때 초기에 분 해율이 높은 것은 흡착되지 않고 토양 공극에 잔류한 농약들이 미생물 활성에 의해 빠르게 분해되었기 때문으로 판단된다.

바이오차 처리에 따른 얼갈이 배추의 시험 농약 흡수·이행 평가 얼갈이 배추를 뿌리, 줄기, 잎 세 부분으로 나뉘어서 농약을 잔 류 분석하였다. 각 부위별 단위중량당 잔류량은 뿌리 > 잎 > 줄 기 순이었다(Fig. 3). 토양 중 농약은 뿌리를 통해 작물로 전이

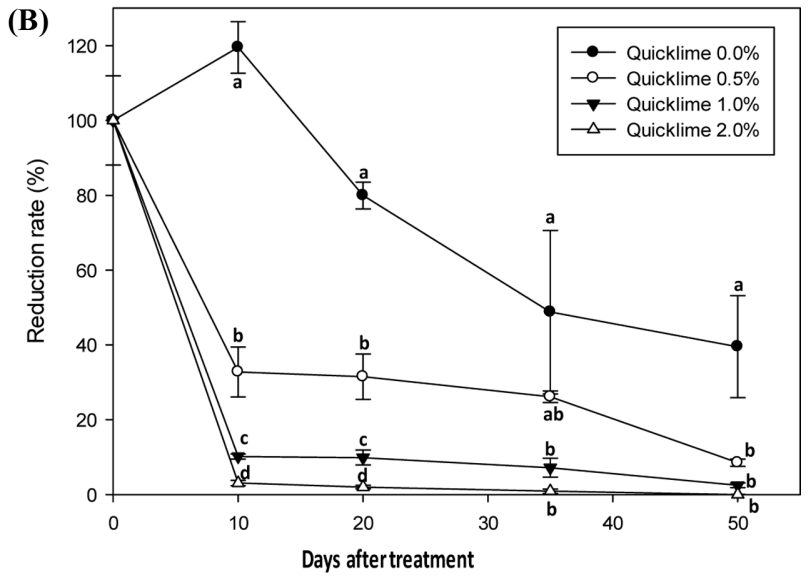

Fig. 1 Reduction effects residual (A) azoxystrobin, (B) procymidone, (C) tricyclazole by different amount of quicklime $(0.5,1.0,2.0 \%)$ in soils

되기 때문에 뿌리의 잔류량이 높게 나타났다[25,26]. 또한 지상 부의 생장은 지하부의 생장보다 활발하여 농약이 희석되는 효 과로 잔류량이 낮아지기 때문에 잎이 뿌리보다 잔류량이 낮게 나타난 것으로 판단된다. 뿌리랑 연결된 줄기의 농약 잔류량이 가장 낮은 이유는 줄기는 식물체 내 물이 이동하는 부위로 물 질이 잔류하기 어려우며, 잎은 작물체의 말단 부위로 물질이 이 동하지 못하고 잔류하기 때문에 줄기보다 잔류량이 높게 나타 났다.

무처리 토양에서 재배한 얼갈이 배추의 농약 전이율(초기농 도 대비 얼갈이 배추 잔류량)은 뿌리, 줄기 및 잎에서 모두 procymidone $>$ tricyclazole $>$ azoxystrobin 순이었다. 토양 중 농 약의 작물체 이동은 옥탄올-물 분배계수 $\left(\mathrm{K}_{\mathrm{ow}}\right.$, 옥탄올 용해도/수 용해도)와 가장 관계가 있는 것으로 알려져 있다(Travis and Arms, 1988). 시험농약의 $\mathrm{K}_{\mathrm{ow}}$ 에 $\log$ 값으로 전환시킨 $\log \mathrm{P}$ 의 값은 procymidone (3.3)> azoxystrobin (2.5)> tricyclazole (1.4) 이지만, 작물 전이량과 일치하지 않았다. 농약의 작물 전이량은 토양 흡착계수 $\left(\mathrm{K}_{\mathrm{oc}}\right)$ 와 반감기를 고려하여 잔류기간과 이동성을 종합적으로 고려해볼 필요가 있다. Procymidone은 $\log \mathrm{P}$ 와 $\mathrm{K}_{\mathrm{oc}}$ 가 tricyclazole보다 높아 이동성이 낮을 것으로 예상되지만, 얼 갈이 배추로의 전이량은 더 높았다.

왕겨숯을 처리한 토양에서 재배한 얼갈이 배추는 왕겨숯 $1.0 \%$ 이상 처리할 때 저감효과가 나타났다 $(p<0.05)$. 

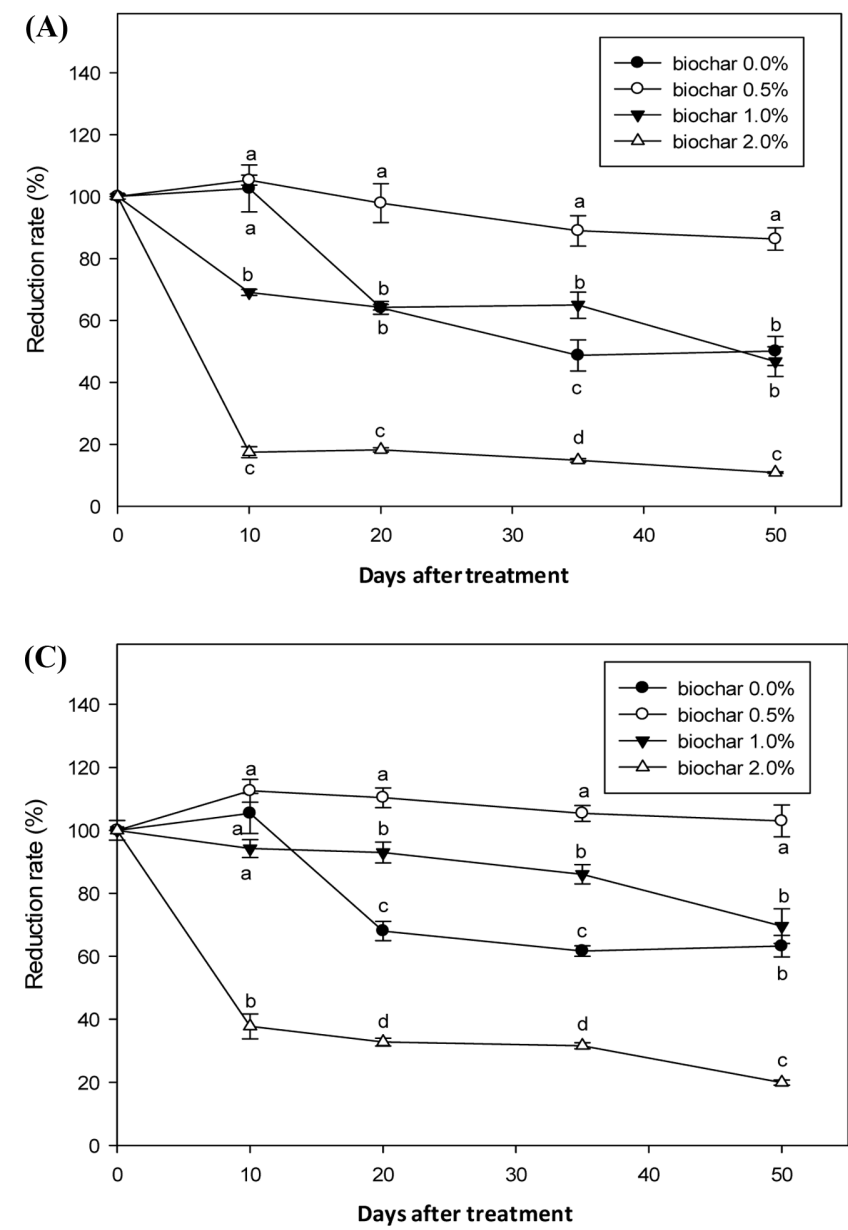

Azoxystrobin은 왕겨숯 $2.0 \%$ 처리한 토양에서 얼갈이 배추 모 든 부위에서 농약이 검출되지 않았다. 왕겨숯 $0.5 \%$ 를 처리할 경우 저감효과가 없었다 $(p>0.05)$. 이러한 이유는 azoxystrobin의 전이량이 낮기 때문에 바이오차를 처리하여도 뚜렷한 차이를 보 이지 않은 것으로 판단된다. $\mathrm{Kim}$ 등[27]의 연구에서 얼갈이 배 추의 azoxystrobin의 전이량 구명 연구에서는 토양 중 $6.0 \mathrm{mg}$ / $\mathrm{kg}$ 을 처리하였을 때도 작물에서 불검출 되었다. 본 연구에서도 뿌리 $(0.11-0.33 \mathrm{mg} / \mathrm{kg})$, 잎 $(0.03-0.09 \mathrm{mg} / \mathrm{kg})$ 에서 전이율이 낮게 나온 양상과 비슷하지만 잔류량의 차이는 토양의 물리 화학적 특성에 따른 차이로 판단된다.

Procymidone은 바이오차 처리구에서는 줄기를 제외하고 저감 효과가 있는 것으로 나타났다 $(p<0.05)$. 줄기에서는 저감효과가 없는 이유는 잔류량이 낮아 저감차이가 없는 것으로 판단된다. 바이오차를 $2.0 \%$ 처리할 경우 무처리 대비 뿌리 $1.62 \mathrm{mg} / \mathrm{kg}$ $(90 \%)$, 잎 $0.29 \mathrm{mg} / \mathrm{kg}(66 \%)$, 줄기 $0.06 \mathrm{mg} / \mathrm{kg}$ (40\%)로 뚜렷 한 저감효과를 확인할 수 있었다.

Tricyclazole은 얼갈이 배추에는 등록이 되어 있지 않은 수도 용 농약으로 논 토양에서 다빈도로 검출되는 농약이다[28]. 최 근 논밭 전환에 따라 기존의 논토양을 밭으로 전환하여 작물을 재배하기 때문에 관리방안이 필요할 것으로 판단된다. 바이오차

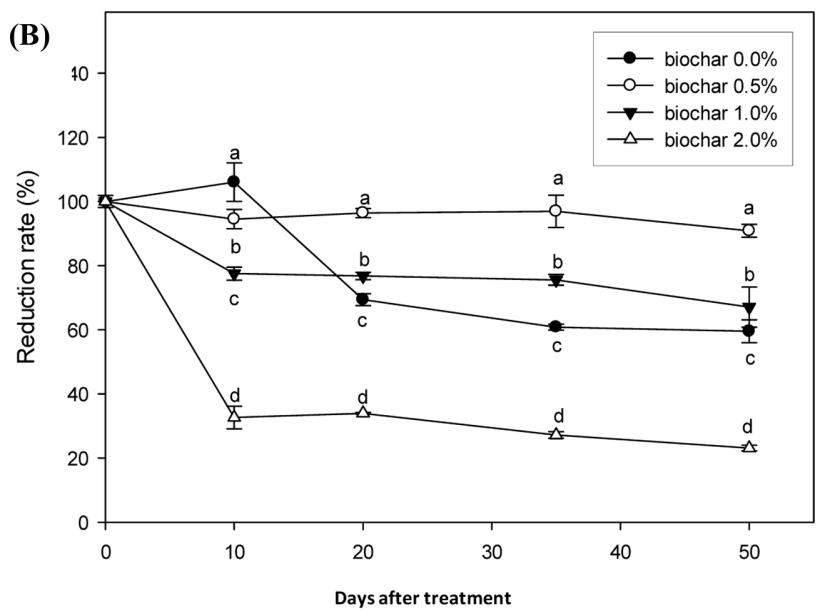

Fig. 2 Reduction effects residual (A) azoxystrobin, (B) procymidone, (C) tricyclazole by different amount of biochar $(0.5,1.0,2.0 \%)$ in soils

$1.0 \%$ 이상 처리할 때 부위별로 $0.06-0.30 \mathrm{mg} / \mathrm{kg}$ 의 잔류량 차이 로 저감효과를 나타냈다 $(p<0.05)$.

바이오차를 처리할 경우 토양과 얼갈이 배추의 잔류량의 상 관관계가 다르게 나타났다. 농약 처리 50 일후 바이오차 $0.5 \%$ 를 처리한 토양 중 azoxystrobin $(2.17 \mathrm{mg} / \mathrm{kg})$, procymidone $(1.93$ $\mathrm{mg} / \mathrm{kg})$, tricyclazole $(2.63 \mathrm{mg} / \mathrm{kg})$ 잔류량 차이는 무처리구 보다 높았지만 얼갈이 배추의 잔류량은 낮았다. 바이오차는 강한 흡 착력을 가지는 물질로서 유기물질이 흡착될 경우 생물학적 및 비생물학적 분해가 일어나지 않는 안정된 형태로 잔류되어 토 양의 잔류량은 높게 나타난다. $\mathrm{Yu}$ 등[24]의 연구에서도 바이오 차를 처리한 토양에 작물체를 재배하여 흡수 - 이행 저감 연구 결과 바이오차를 처리할 경우 토양 잔류량은 무처리구 보다 높 았지만 작물체 전이량은 낮았다.

토양 중 농약 안전성을 향상시키는 바이오차는 토양 미생물 활성 및 물리화학적 특성을 개선시켜 작물 생육에도 유리한 것 으로 보고되고 있다[29]. PLS 시행에 따라 토양 중 비의도적 오염은 중요한 문제로 인식되고 있는데, 바이오차는 부정적 영 향을 최소화 하고 농약 안전성 문제를 해결할 수 있는 현실적 인 대안이 될 수 있을 것으로 생각된다. 

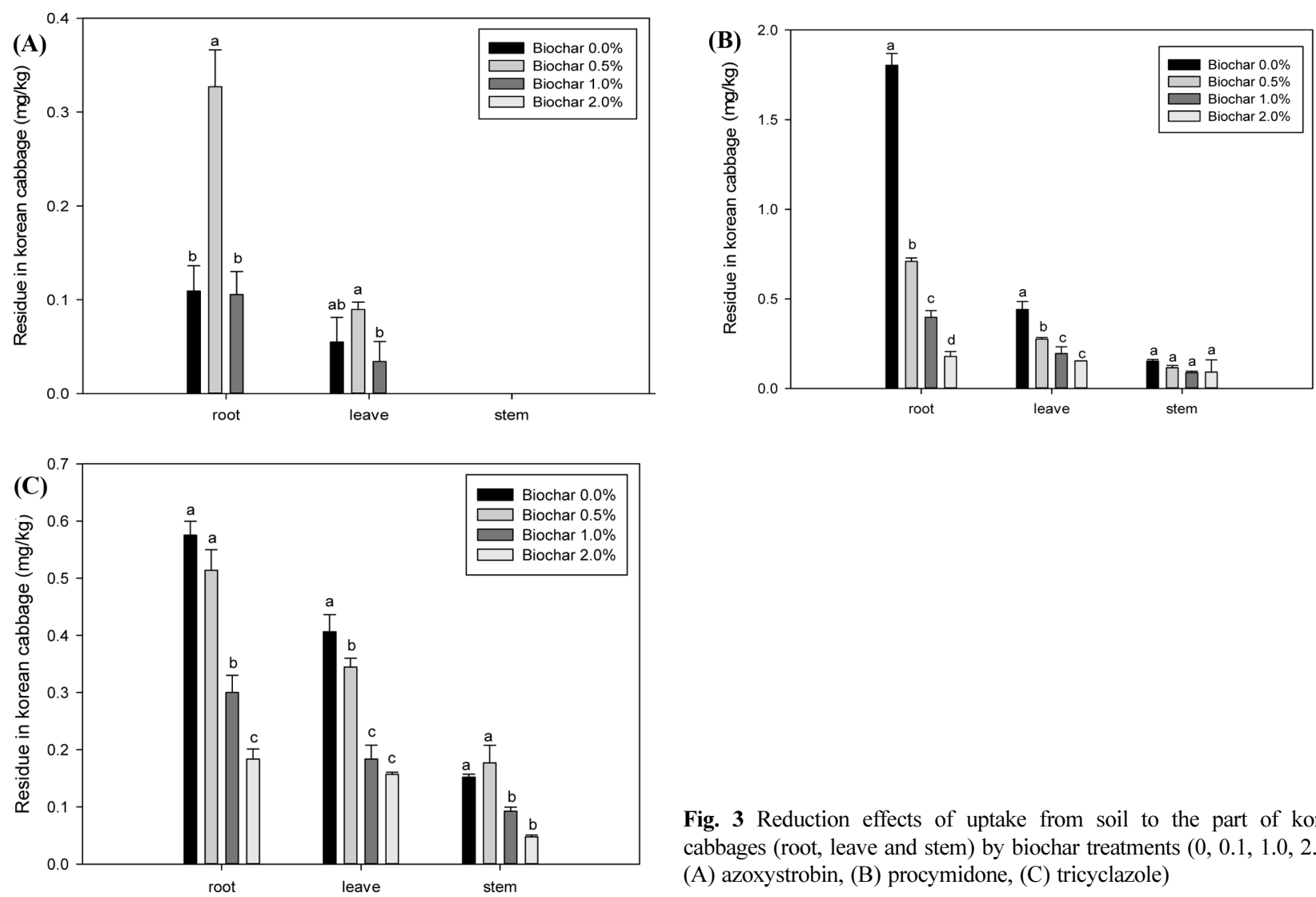

Fig. 3 Reduction effects of uptake from soil to the part of korean cabbages (root, leave and stem) by biochar treatments $(0,0.1,1.0,2.0 \%$, (A) azoxystrobin, (B) procymidone, (C) tricyclazole)

\section{초 록}

농약의 안전범위 확대와 Positive List System이 시행되면서 토 양 중 농약 안전관리방안에 대한 관심이 증가하였다. 토양 중 농약 안전관리를 위해서는 농경지 내 잔류량 저감화와 농산물 전이 저감방안이 대표적이다. 이번 연구에서는 토양 중 농약 안 전성 향상을 위해서 시험농약은 azoxystrobin, procymidone 및 tricyclazole을 사용하였고, 저감화 방법으로 바이오차와 생석회 를 이용했다. 실험방법은 토양에 바이오차와 생석회를 토양 $(15$ $\mathrm{cm})$ 무게 기준 $0,0.5,1.0,2.0 \%$ 를 첨가한 후 $0,10,20,35$, 50 일 동안 경시적 잔류양상을 확인하였다. 바이오차 처리에 의 한 작물 흡수 - 이행 저감효과 구명을 위해 얼갈이 배추의 뿌 리, 잎, 줄기로 나뉘어 잔류량을 분석했다. 실험결과 생석회 처 리할 때 2.0\% 처리할 때 azoxystrobin (36-96\%), procymidone (40-117\%), tricyclazole (26-83\%) 저감효과가 있었다 $(p<0.05)$. 바이오차 처리할 때 $1.0 \%$ 이하 처리할 때 토양 중 잔류량 저 감효과는 없었다. 그러나 바이오차 $2.0 \%$ 처리한 토양에서 재배 한 얼갈이 배추의 뿌리 $(0.11-1.62 \mathrm{mg} / \mathrm{kg})$, 잎 $(0.05-0.29 \mathrm{mg} / \mathrm{kg})$, 줄기 $(0.06-0.1 \mathrm{mg} / \mathrm{kg})$ 에서 전이량이 감소되었다 $(p<0.05)$. 생석회 와 바이오차는 농업에 활용성이 높은 토양개량제로 농약 안전 관리방안에 이용할 수 있는 방법으로 판단된다.

Keywords 농약 - 바이오차 - 생석회 · 저감효과 · 흡수이행

감사의 글 본 연구는 농촌진흥청 국립농업과학원 농업과학기술 연구개발사 업(과제번호:PJ0126002020)의 지원에 의해 이루어진 것임

\section{References}

1. Noh HO, Lee JY, Park SH, Jeong OS, Kim SH, Kyung KS (2012) Monitoring of pesticide residues in rice paddy soil and paddy water. Korean J Pestic Sci 16(2): 137-144

2. Marín-Benito JM, Brown $\mathrm{CD}$, Herrero-Hernández E, Arienzo $\mathrm{M}$, Sánchez-Martín MJ Rodríguez-Cruz MS (2013) Use of raw or incubated organic wastes as amendments in reducing pesticide leaching through soil columns. Science of the Total Environment 463-464: 589-599

3. Lee HS, Hong SM, Kim TK, Kwon HY, Kim DB, Moon BC, Moon JK (2016) Reduction Effects of Residual Pesticides using the Eco-Friendly Soil Amendments in Agricultural Soil. Korean J Pestic Sci 16(2): 137144

4. Kim JY, Kim HN, Saravanan M, Heo SJ, Jeong HN, Lim JE, Kim KR, Hur JH (2014) Translocation of tolclofos-methyl from ginseng cultivated soil to ginseng (Panax ginseng C A Meyer) and residue analysis of various pesticides in ginseng and soil. Korean J Pestic Sci 18(3): 130140

5. Jeon SO, Hwang JI, Lee SH, Kim JE (2014) Uptake of boscalid and chlorfenapyr residues in soil into Korean cabbage. Korean J Pestic Sci 18(4): 314-320

6. Hwang JI, Jeon SO, Lee SH, Lee SE, Hur JH, Kim KR, Kim JE (2014) Distribution patterns of organophosphorous insecticide chlorpyrifos 
absorbed from soil into cucumber. Korean J Pestic Sci 18(3): 148-155

7. Kim SM, Jo IG, Gyeon GS, Lee JK (2003) Influence of soil organic matter and moisture on the persistence of the herbicide mefenacet in soils. Korean J Pestic Sci 7(3): 182-187

8. Park BJ, Kim CS, Park KH, Park HJ, Im GJ, Choi JH, Shim JH, Rye GH (2006) Distribution and Mobility of Herbicide 14C-Molinate in a RicePaddy-Soil Lysimeter. Korean J Pestic Sci 10(3): 172-182

9. Blackwell P, Krull E, Butler G, Herbert A, Solaiman Z (2010) Effect of banded biochar on dryland wheat production and fertilizer use in southwestern Australia: an agronomic and economic perspective. Aust J Soil Res 48 (7): 531-545

10. Tang J, Zhu W, Kookana R, Katayama A (2013) Characteristics of biochar and its application in remediation of contaminated soi.l J Biosci Bioeng 116 (6): 653-659

11. Ahmad M, Rajapaksha AU, Lim JE, Zhang M, Bolan N, Mohan D (2014) Biochar as a sorbent for contaminant management in soil and water: A review. Chemosphere 99: 19-33

12. Jones DL, Edwards-Jones G, Murphy DV (2011) Biochar mediated alterations in herbicide breakdown and leaching in soil. Soil Biol Biochem 43 (4): 804-813

13. Cabrera A, Cox L, Spokas L, Hermosin MC, Cornejo J, Koskinen WC (2014) Influence of biochar amendments on the sorption-desorption of aminocyclopyrachlor, bentazone and pyraclostrobin pesticides to an agricultural soi.l Sci Total Environ 470-471: 438-443

14. Dechene A, Rosendahl I, Laabs V, Amelung W (2014) Sorption of polar herbicides and herbicide metabolites by biocharamended soil. Chemosphere 109: 180-186

15. Chun BS, Ko KS (1998) Improvement effect of marine clay in yul-chon by quick Lime pile. J Korean Soci Civil Engin 18(2-4): 521-529

16. Kim YH, Chu BS (2010) Improvement effects of soft clay soils using quick lime piles. J the Korean Geoenviron Society 11(5): 45-51

17. Jung KH, Seo IW, Nam HJ, Shin HS (2008) Effects of Ozonated Water Treatment on Pesticide Residues and Catechin Content in Green Tea Leaves. Korean J Food Sci Technol 40(3): 265-270

18. Yan M, Binbin D, Xiaosong H, Yi S, Mingyue X, Xuwen H, Xiaoming D, Fasheng L (2017) Quicklime-induced chages of soil properties: Implications for enganced remedation of volatile chlorinated hydrocarbon contaminated soils via mechanical soil aeration. Chemosphere 173: 435443

19. Zhang P, Sheng G, Feng Y, Miller DM (2006) Predominance ofchar sorption over substrate concentration and soil $\mathrm{pH}$ in influencing biodegradation of benzonitrile. Biodegradation 17 (1): 1-8

20. Qiu Y, Pang H, Zhou Z, Zhang P, Feng Y, Sheng DG (2009) Competitive biodegradation of dichlobenil and atrazine coexisting in soil amended with a char and citrate. Environ Pollut 157 (11): 2964-2969

21. Lopez-Pineiro A, Pena D, Albarran A, Sánchez-Llerena J,Becerra D (2013) Behavior of MCPA in four intensive croppingsoils amended with fresh, composted, and aged olive mill waste. J Contam Hydrol 152: 137 146

22. Leng L,Huang H, Li H, Li J, Zhou W (2019) Biochar stability assessment methods: a review. Science of the total environment 647: 210-222

23. Shaheen SM, Niazi NK, Hassan NE, Bibi I, Wang H, Tsang DC, Ok YS, Bolan N, Rinklebe J (2019) Woodbased biochar for the removal of potentially toxic elements in water and wastewater: a critical review. International Materials Reviews 64(4): 216-247

24. Yu XY, Ying GG, Kookana RS (2009) Reduced plant uptake of pesticides with biochar additions to soil. Chemosphere 76: 665-671

25. Chu WK, Wong MH, Zhang J (2006) Accumulation, distribution and transformation of DDT and PCBs by Phragmites australis and Oryza sativa L: I Whole plant study Environ Geochem Health 28: 159-168

26. Whitfield AML, Zeeb BA, Rutter A, Reimer KJ (2007) In situ phytoextraction of polychlorinated biphenyls residues in vegetables, grain and soil from organic and conventional farming in Poland. $\mathrm{J}$ Environ Sci health B 47: 343-353

27. Kim MG, Hwang KW, Hwang EJ, Yoo SC, Moon JK (2017) Translocation of Residual Azoxystrobin from Soil to Korean Cabbage. Korean J Pestic Sci 21(4): 427-433

28. Park BJ, Lee BM, Kim CS, Park KH, Park SW, Kwon HY, Kim JH, Choi GH, Lim SJ (2013) Long-term Monitoring of Pesticides Residues in Arable Soils in Korea. Korean J Pestic Sci 17(4): 283-292

29. Khorram MS, Zhang Q, Lin D, Zheng Y, Fang H, Yu Y (2016) Biochar: A review of its impact on pesticide behavior in soil environments and its potential applications. J Environ Sci 44: 269-279 